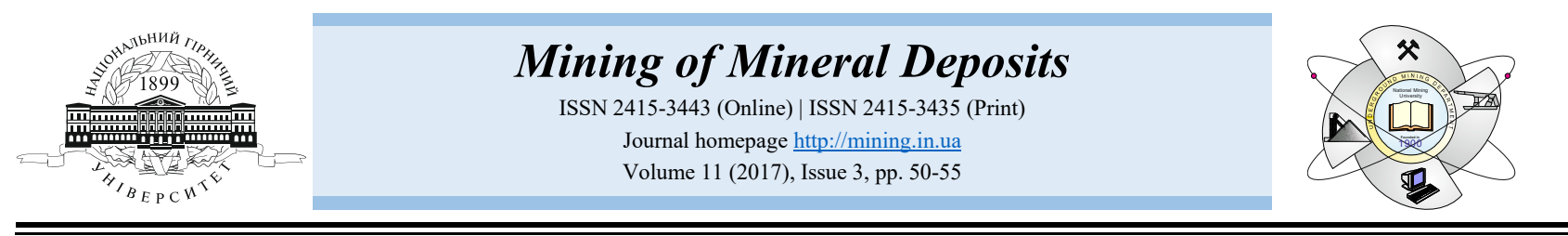

UDC 622.062:624.191.6

https://doi.org/10.15407/mining11.03.050

\title{
SCALE FACTORS FOR CONVERSION OF FORCES ON DISC CUTTERS FOR THE MAIN DOMESTIC AND FOREIGN METHODS
}

\author{
A. Zhabin ${ }^{1 *}$, A. Polyakov ${ }^{1}$, E. Averin ${ }^{2}$ \\ ${ }^{1}$ Geotechnologies and Underground Construction Department, Tula State University, Tula, Russia \\ 2Designing Department, LLC "SOEZ”, Tula, Russia \\ *Corresponding author: e-mail zhabin.tula@mail.ru, tel.+74872333155, fax:+74872333155
}

\section{МАСШТАБНІ КОЕФЩЦЕНТИ ПЕРЕРАХУНКУ ЗУСИЛЬ НА ДИСКОВИХ ШАРОШКАХ ДЛЯ ОСНОВНИХ ВІТЧИЗНЯНИХ І ЗАРУБІЖНИХ МЕТОДІВ}

\author{
А. Жабин ${ }^{1 *}$, А. Поляков ${ }^{1}$, Е. Аверин ${ }^{2}$ \\ ${ }^{1}$ Кафедра геотехнологий и строительства подземных сооружений, Тульский государственный университет, Тула, Россия \\ ${ }^{2}$ Конструкторско-технологический отдел, ООО “СОЭЗ”, Тула, Россия \\ *Ответственный aвтор: e-mail zhabin.tula@mail.ru, тел. +74872333155, факс: +74872333155
}

\begin{abstract}
Purpose. Disc cutter is an important tool which is used in tunneling to destroy the rock during excavation as it directly influences rock-breaking efficiency, advance rate and economy of a project. Thus, it is of critical importance to have a reliable and accurate method for making predictions on cutting forces during rock destruction by disc cutters. Russian (including Soviet) research in the field is limited by studying small-diameter and/or wedge-shaped disc cutters which are not currently used. This paper is meant to coordinate domestic research by Baron and Glatman with the most widely used and fully accepted foreign theoretical and semi-empirical methods (by Roxborough and Phillips, Bilgin and Phillips, and Rostami and Ozdemir) that have proven accurate and reliable for TBM (tunnel boring machine) performance prediction.
\end{abstract}

Methods. The analysis of methods includes a brief review, a series of numerical experiments, which were performed for disc cutters with diameters 160 and $483 \mathrm{~mm}$, and a comparison with the use of graphs. Then by approximation of the data obtained in this way, we have derived formulas for converting values of cutting forces gained by foreign methods into the values suitable for the same conditions and the domestic method.

Findings. The method by Baron and Glatman itself could not be used for TBM performance prediction and tunneling planning nowadays. The approach based on the scale factors could be used for correlating any of the represented methods. Scale factors depend on the depth of cut (DOC) for rolling forces or on DOC and disc cutter diameter for normal forces.

Originality. The analysis has also shown that mutual arrangement of the graph lines for all figures remains unchanged. The invariance of the relative positioning and trends of the graph lines allowed to assume that it is possible to introduce scale factors which help to convert values from one method into the values of other methods. The scale factor, which enables to relate domestic method and the main foreign methods, is determined by consecutive division of the calculated values obtained via the method of Baron and Glatman by the values used in other considered methods.

Practical implications. The results could be used in TBM designing and in tunneling projects.

Keywords: rock cutting, mechanical tool, disc cutter, domestic and foreign methods, cutting force, scale factor, correlation of calculation methods

\section{INTRODUCTION}

Development of tunneling technology for underground space has led to a situation when the face rock tunnel boring machine (TBM) has become a standard technical means for excavating in a wide range of mining and civil construction projects. In comparison with the conventional drill-and-blast method such machines provide not only high advance rate, especially in favorable ground conditions, and excellent working safety, but also reduce the extent of damage. Therefore, TBM has been widely applied to construct tunnels for subways, railways, 
highways and hydro-power projects, etc. including projects in challenging conditions, such as urbanized environment and in adverse mining and geological conditions (Alber, 2008; Cho, Jeon, Yu, \& Chan, 2010; Festa, Broere, \& Bosch, 2012; Gong, Yin, Ma \& Zhao, 2016).

Proper selection of TBMs is vital for improving efficiency of excavation and reducing costs in tunneling projects. The principal design and performance parameters of TBM are machine diameter, its power, torque, thrust, RPM of the cutterhead, cutter type and size, rock mass properties, and geological conditions (Balci \& Tumac, 2012). The key issue for TBM excavation is to match the rock properties and the operational parameters of the machine (Zhao, Gong, \& Eisensten, 2007). The efficiency of rock excavation depends on the cutter geometry and the cutting pattern used (Cho, Jeon, Jeong, \& Chang, 2013). Therefore, the prior task in meeting the challenges mentioned above is to estimate forces acting on the rock cutting tools during operational process.

The standard tools for excavation by TBMs are disc cutters, which are used on a wide range of tunneling equipment and in different geological conditions. Disc cutter is an important tool of TBM to crush the rock during excavation as it directly influences rock-breaking ability, boring speed and economic indexes (Li, Cai, \& Kang, 2011). Thus, it is of critical importance in planning tunneling projects, to have a reliable and accurate method for making predictions on cutting forces during rock destruction by disc cutters. Russian (including Soviet) research in the field is limited to studying small-diameter and/or wedge-shaped disc cutters (Mamet'ev, Khoreshok, Tsekhin, \& Borisov, 2015; Preis \& Kuznetsov, 2015; Zhelikevich, Selivanov, \& Kaiser, 2015; Karkashadze \& Babich, 2017), which are no longer used in tunneling.

\section{EXISTING METHODS FOR ESTIMATING CUTTING FORCES FOR DISC CUTTERS}

The most widely used classical domestic method was elaborated by Baron et al. (1977). It is represented in (Solod, Getopanov, \& Rachek, 1982) with reference to the work (Baron, Glatman, Gubenkov, \& Zagorskij, 1977):

$$
\begin{aligned}
& F_{R}=0.326 e^{21 s}(190 p+0.24) K_{1} K_{2} ; \\
& F_{N}=0.306 e^{21 s} K_{1} K_{3}(170 p+0.32)(3.5 D+0.64),
\end{aligned}
$$

where:

$F_{R}$ - the rolling force, $\mathrm{kN}$;

$F_{N}-$ the normal force, $\mathrm{kN}$;

$e$ - the base of the natural logarithm;

$s-$ the cutter spacing, $\mathrm{m}$;

$p$ - the penetration, $\mathrm{m}$;

$D$ - the disc cutter diameter, $\mathrm{m}$;

$K_{1}$ - the coefficient related to the cutting edge parameters;

$K_{2}$ and $K_{3}-$ coefficients of the rock strength.

Coefficients could be derived from:

$$
K_{1}=(220 r+0.78)(0.0068 \beta+0.73) \text {, }
$$

where:

$r$ - the radius of cutting edge dulling, $\mathrm{m}$;

$\beta$ - the angle of the edge tapering, degree.

$$
\begin{aligned}
& K_{2}=0.0089 P_{k}-0.0016 \cdot 10^{-3} P_{k}^{2}+1.22 ; \\
& K_{3}=0.0435 P_{k}-0.0045 \cdot 10^{-3} P_{k}^{2}+5.28,
\end{aligned}
$$

where:

$P_{k}-$ the rock contact strength in $\mathrm{MPa}$;

All the main parameters affecting the process of rock fragmentation by disc cutters are fully represented in equations (1) and (2). However, it is evident that they are empirical. For this reason, it is impossible to apply these equations to conditions different from those for which they were obtained, at least without preliminary studies for their compliance with the actual process or theoretical models. This paper aims to correlate the domestic research by Baron et al. (1977) with the most widely used and fully accepted foreign theoretic and semi-empirical methods, which have proven accurate and reliable for TBM performance prediction.

Two types of disc cutters are commonly used for equipping TBM: V-type (wedge shaped) and CCS (constant cross section). V-type cutters are no longer used, except in special cases (Balci \& Tumac, 2012), because of uneven wear of the cutter tips, which progressively changes the contact area with the rock. So they have been replaced with CCS disk cutters. At present, the CCS type of disk cutters with diameter of $330-508 \mathrm{~mm}(13-20$ inches) is commonly used, since it is able to bear higher cutter loads and ensure higher efficiency, (Bilgin, Copur, $\&$ Balci, 2014). The most popular disc cutter type for TBMs is the CCS disc cutter with diameter $432 \mathrm{~mm}$ (17 inches) (Rostami, 2013).

The model developed by Roxborough \& Phillips (Roxborough \& Phillips, 1975; Roxborough, 1978) is widely used to estimate the normal and rolling forces acting on a V-type disc cutter. This model describes the normal forces acting on a V-type disc cutter, assuming that the normal force equals the compressive strength of the rock $\left(\sigma_{c}, \mathrm{MPa}\right)$ multiplied by the projected area of the disc contact area in the velocity vector direction. Normal force ensures the tool penetration into the rock at a certain depth $(p, \mathrm{~mm})$ for a disc cutter of the set edge angle $(\beta$, deg. $)$ and diameter $(D, \mathrm{~mm})$. As penetration increases, so does the arc of the disc cutter contact with rock.

Thus, the normal force could be presented as:

$F_{N}=4 \sigma_{c} \tan \frac{\beta}{2} \sqrt{D p^{3}-p^{4}}$.

The rolling force acting on the disk is calculated with assumption in mind that the resultant force passes through the center of rotation:

$F_{R}=4 \sigma_{c} p^{2} \tan \frac{\beta}{2}$.

This model was elaborated for the ideally sharp edge of the disc cutter. However, in practice, V-type disk cutters have an obtusion which is expressed by the radius of cutting edge rounding, changing from $1 \mathrm{~mm}$ to a few millimeters. In this case, the predicted rock-cutting force values need to be corrected taking into account the rounding radius $(r, \mathrm{~mm})$. Such modification (Bilgin, 1977; Phillips \& Bilgin, 1977; Phillips, Bilgin, \& Price, 1978) of the model described above was developed by Bilgin and Phil- 
lips with the view to correcting the mean values of normal and rolling forces on the sharp tool:

$$
\begin{aligned}
& F_{N}^{\prime}=F_{N} \exp \left(r\left(0.0354+\frac{0.6554}{p}\right)\right) ; \\
& F_{R}^{\prime}=F_{R} \exp \left(r\left(0.06+\frac{0.383}{p}\right)\right) .
\end{aligned}
$$

The CCS disc cutters are preferred due to higher resilience to loads and better efficiency compared to V-type disc cutters (Tumac \& Balci, 2015). Rostami and Ozdemir developed a theory of rock destruction by CCS cutters (Rostami \& Ozdemir, 1993; Rostami, Ozdemir, \& Nilson, 1996) which allows to determine pressure in the zone of disc cutter interaction with rock. As disc cutters penetrate the rock, a crushed zone extends beneath the cutter due to radial tensile cracks propagation. When these cracks coalesce with other cracks created from neighboring cuts or reach the free surface, then rock spalling occurs. This process is known as the rock fragmentation mechanism.

Normal and cutting forces are defined as projections of the resultant force onto the respective axes:

$$
\begin{aligned}
F_{N}= & \frac{2.12 \cdot 3 \sqrt[3]{\frac{s \sigma_{c}^{2} \sigma_{t}}{\gamma \sqrt{R T}} R T \gamma}}{1+\psi} \cdot \cos \frac{\gamma}{2} \\
F_{R}= & \frac{2.12 \cdot 3 \sqrt{\frac{s \sigma_{c}^{2} \sigma_{t}}{\gamma \sqrt{R T}}} R T \gamma}{1+\psi} \cdot \sin \frac{\gamma}{2}
\end{aligned}
$$

where:

$R$ - disc cutter radius, $\mathrm{mm}$;

$T$ - the width of the cutting edge, $\mathrm{mm}$;

$\psi$ - the coefficient describing load distribution function, which decreases from 0.2 to -0.2 with the increase in the width of the cutting edge;

$s$ - the cutter spacing, mm;

$\sigma_{t}$ - the threshold tensile strength of the rock, $\mathrm{MPa}$;

$\gamma$ - the angle of contact between the disc cutter and the rock, which is calculated by the equation:

$\gamma=\arccos \frac{R-p}{R}$

where:

$p$ - the depth of cut, mm.

In order to distinguish between the methods described above we will call them by the names of their authors. So equations (1) and (2) relate to Baron \& Glatman method, equations (6) and (7) to Roxborough \& Phillips method, equations (8) and (9) to Bilgin \& Phillips method, and equations (10) and (11) to Rostami \& Ozdemir method.

Preliminary analysis of the methods under consideration shows that the most complete list of influencing parameters is present in the Baron \& Glatman and Rostami \& Ozdemir methods. Apart from cutter spacing, the Bilgin \& Phillips' list is complete enough. As Roxborough \& Phillips method was developed for an ideally sharp cutter, its list of parameters lacks not only cutter spacing, but also rounding of the cutting edge.
It should also be noted that not a single method, except the method of Rostami and Ozdemir, takes into account the cutter's size parameters when calculating rolling force.

\section{RESULTS AND DISCUSSION}

For further investigation, it is necessary to perform numerical experiments. The following parameters were taken as constants during the study: cutter spacing $85 \mathrm{~mm}$, cutting edge angle $90^{\circ}$, edge rounding radius $1.4 \mathrm{~mm}$, edge width $15 \mathrm{~mm}$, threshold compressive strength $80 \mathrm{MPa}$ and tensile strength $8 \mathrm{MPa}$. To perform calculations by Baron and Glatman method, we obtained the contact strength value $(799.55 \mathrm{MPa})$ using the following equation from (Baron, Glatman, Gubenkov, \& Zagorskij, 1977; Solod, Getopanov, \& Rachek, 1982):

$P_{k}=13 \sigma_{c}^{0.94}$.

During the calculations, the values of the cutting depth varied from 0 to $15 \mathrm{~mm}$ with a step of $1 \mathrm{~mm}$. Calculations were performed for disc cutters with diameters 160 and $483 \mathrm{~mm}$. The first diameter value was chosen to represent small sized disc cutters for which the Baron and Glatman method was designed, and the second one was chosen as the most widely used nowadays.

Figures 1 and 2 show the results of the numerical experiments aiming to determine the normal force for disc cutters of diameters 160 and $483 \mathrm{~mm}$ respectively while Figures 3 and 4 show the results for the rolling force.

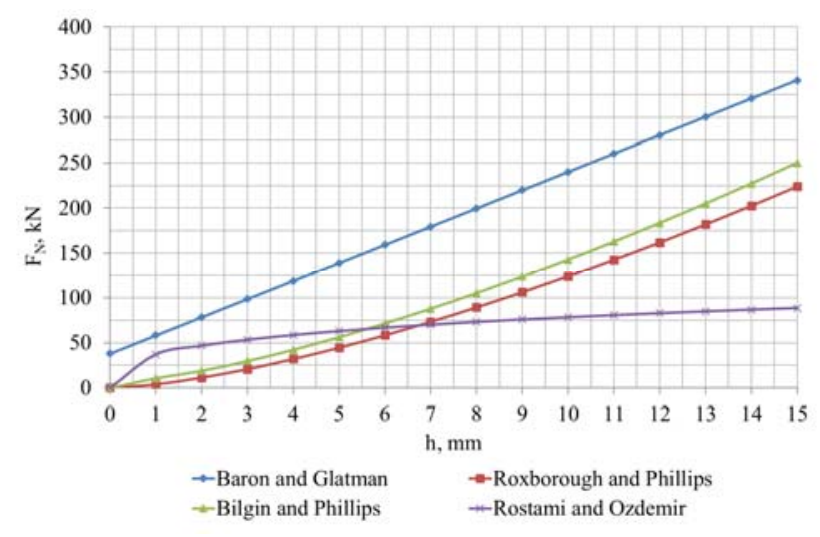

Figure 1. Comparison of normal forces obtained by different methods for disc cutters $D=160 \mathrm{~mm}$

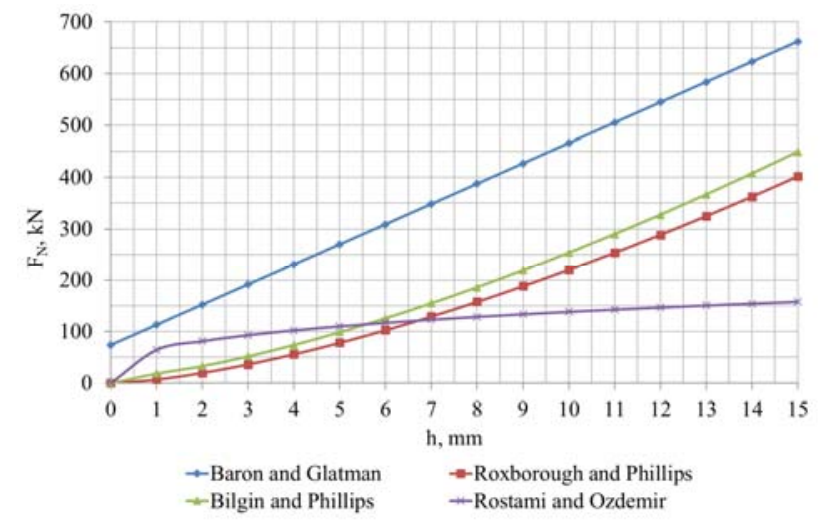

Figure 2. Comparison of normal forces obtained by different methods for disc cutters $D=483 \mathrm{~mm}$ 


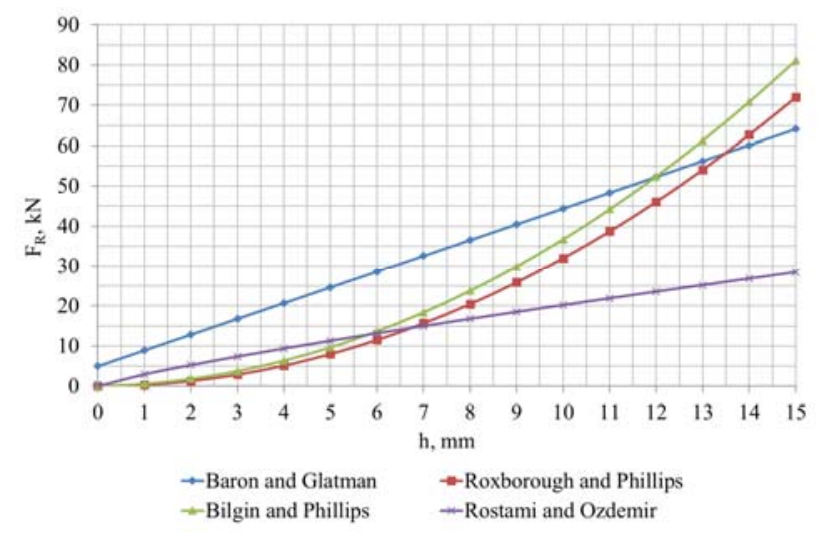

Figure 3. Comparison of rolling forces obtained by different methods for disc cutters $D=160 \mathrm{~mm}$

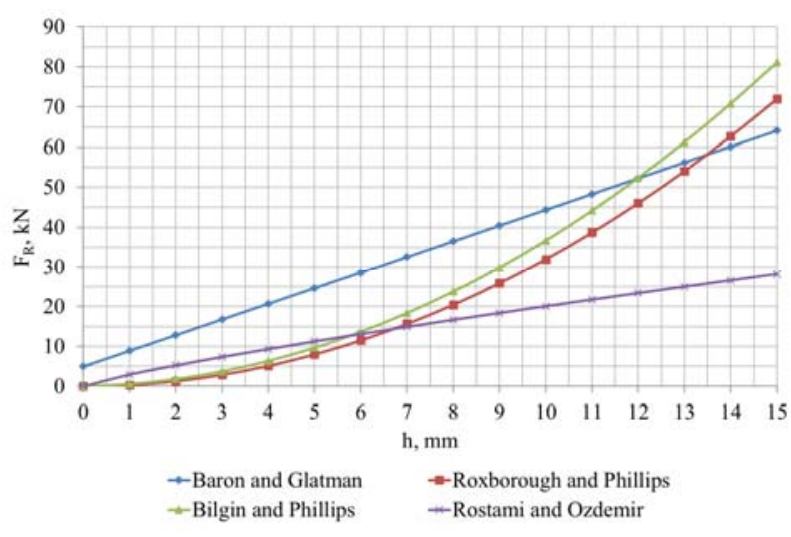

Figure 4. Comparison of rolling forces obtained by different methods for disc cutters $D=483 \mathrm{~mm}$

As seen from Figures 1 and 2, theories of rock destruction for different types of disc cutters describe the process in completely different ways. It is evident from the fact that the graph corresponding to the method of Rostami and Ozdemir does not coincide with the trends of other methods. As the Bilgin and Phillips method takes into account blunting of the cutting edge, it is expected to result in slightly higher force values than those for Roxborough and Phillips method for an ideally sharp tool. Mutual arrangement of the graph lines for both Figures remains unchanged (if you do not pay attention to the values along the ordinate axis, the drawings seem to be identical). The invariance of the relative positioning and trends of the graph lines makes it possible to assume that it is possible to introduce scale factors that allow to convert values from one theory to the values of other theories.

The fact that rolling forces do not depend on the disc size (for the case of wedge-shaped disk cutters) was noted at the stage of preliminary analysis of the equations (1), (7), and (9). However, in spite of the formal presence of the edge radius in the Rostami and Ozdemir method, proceeding from the graphs shown in Figures 3 and 4, we can conclude that this parameter has an insignificant effect on the value of the rolling force for the CCS disc cutters. When the diameter of the cutter is more than tripled, the change in the values of the rolling force in the graphs is barely noticeable. As for the rest, the conclusions inferred from Figures 3 and 4 coincide with conclusions from Figures 1 and 2.
So let us determine the scale factor, which allows to relate the domestic method with the main foreign methods. For this purpose, it is necessary to consistently divide the calculated values obtained with the help of the Baron and Glatman method by values of other methods under consideration. Then by approximation of the data thus obtained we will get expressions for recalculating values of forces from the foreign methods into the domestic method:

$$
\begin{aligned}
& M_{N}^{R P}=h^{-0.8}\left(3 \cdot 10^{-5} D^{2}-0.011 D+13.64\right) ; \\
& M_{R}^{R P}=24.3 h^{-1.24} ; \\
& M_{N}^{B P}=h^{-0.53}\left(10^{-5} D^{2}-0.005 D+6.456\right) ; \\
& M_{R}^{B P}=14.85 h^{-1.08} ; \\
& M_{N}^{R O}=\left(6 \cdot 10^{-7} D^{2}+0.21\right) h+3 \cdot 10^{-6} D^{2}-0.001 D+1.51 ; \\
& M_{R}^{R O}=h^{-0.08}\left(2 \cdot 10^{-7} D^{2}+6.779\right) .
\end{aligned}
$$

The upper indexes in the equations (14) - (19) relate to the method from which recalculation should be done. So, $R P$ stands for Roxborough and Phillips, $B P$-for Bilgin and Phillips, and $R O$ for Rostami and Ozdemir. The lower indexes show the type of forces: $N$ stands for the normal force, and $R$ - for the rolling force. Except the equation (19), all the other scale factors have high values of the coefficient of determination $\left(R^{2}\right)$ within the range of 0.82 up to 0.99 .

\section{CONCLUSIONS}

Recalculation with the use of scale factors should be done according to the following scheme. If the value of a force estimated by a foreign method is $F_{f}$, then, to obtain a corresponding value for the domestic method $F_{d}$, it is necessary to use the following equation with the scale factor $M$ :

$$
F_{d}=M \cdot F_{f} .
$$

The approach based on the scale factors could be used for recalculation between any of the represented methods. Hence, if there is a need to recalculate values from method A into method B, it should be done by the formula:

$b=\frac{M_{a}}{M_{b}} \cdot a$,

where:

$a$ and $b$ - values obtained by the methods A and B;

$M_{a}$ and $M_{b}$ - scale factors for the methods A and B.

Thereby, the values of cutting forces obtained by the domestic method differ from the foreign calculation methods. So the method itself could not be used for TBM performance prediction and tunneling planning. However, the obtained values can be converted with the help of scale factors that only depend either on the penetration for rolling forces (except Rostami and Ozdemir method) or on the penetration and disc cutter diameter for normal forces and rolling forces (for Rostami and Ozdemir method). 


\section{ACKNOWLEDGEMENTS}

The authors express their deepest gratitude to the management and personnel of LLC "SOEZ" (Tula, Russia) for assistance and consultations during the research.

\section{REFERENCES}

Alber, M. (2008). Stress Dependency of the Cerchar Abrasivity Index (CAI) and its Effects on Wear of Selected Rock Cutting Tools. Tunnelling and Underground Space Technology, 23(4), 351-359.

https://doi.org/10.1016/j.tust.2007.05.008

Balci, C., \& Tumac, D. (2012). Investigation into the Effects of Different Rocks on Rock Cuttability by a V-type Disc Cutter. Tunnelling and Underground Space Technology, (30), 183-193. https://doi.org/10.1016/j.tust.2012.02.018

Baron, L.I., Glatman, L.B., Gubenkov, E.K., \& Zagorskij, S.L. (1977). Razrushenie gornyh porod prohodcheskimi kombajnami. Razrushenie agregirovannymi instrumentami. Moskva: Nauka.

Bilgin, N. (1977). Investigations into the Mechanical Cutting Characteristics of Some Medium and High Strength Rocks. $\mathrm{PhD}$. University of Newcastle Upon Tyne.

Bilgin, N., Copur, H., \& Balci, C. (2014). Mechanical Excavation in Mining and Civil Industries. London: CRC Press, Taylor \& Francis Group

Cho, J.-W., Jeon, S., Yu, S.-H., \& Chang, S.-H. (2010). Optimum Spacing of TBM Disc Cutters: A Numerical Simulation using the Three-dimensional Dynamic Fracturing Method. Tunnelling and Underground Space Technology, 25(3), 230-244. https://doi.org/10.1016/j.tust.2009.11.007

Cho, J., Jeon, S., Jeong, H., \& Chang, S. (2013). Evaluation of Cutting Efficiency during TBM Disc Cutter Excavation within a Korean Granitic Rock using Linear-cuttingmachine Testing and Photogrammetric Measurement. Tunnelling And Underground Space Technology, (35), 37-54. https://doi.org/10.1016/j.tust.2012.08.006

Festa, D., Broere, W., \& Bosch, J. (2012). An Investigation into the Forces Acting on a TBM during Driving - Mining the TBM Logged Data. Tunnelling and Underground Space Technology, (32), 143-157. https://doi.org/10.1016/j.tust.2012.06.006

Gong, Q., Yin, L., Ma, H., \& Zhao, J. (2016). TBM Tunnelling under Adverse Geological Conditions: An Overview. Tunnelling and Underground Space Technology, (57), 4-17. https://doi.org/10.1016/j.tust.2016.04.002

Karkashadze, G.G., \& Babich, A.V. (2017). Study of the Process of Rock Failure of Disc Cutters. Mining Informational and Analytical Bulletin (Scientific and Technical Journal), (1), 109-116.

Li, F., Cai, Z., \& Kang, Y. (2011). A Theoretical Model for Estimating the Wear of the Disc Cutter. Applied Mechanics and Materials, (90-93), 2232-2236.

https://doi.org/10.4028/www.scientific.net/amm.90-93.2232
Mamet'ev, L., Khoreshok, A., Tsekhin, A., \& Borisov, A. (2015). Stress Distribution in Attachments of Disc Cutters in Heading drivage. Journal of Mining Science, 51(6), 1150-1156. https://doi.org/10.1134/s1062739115060427

Phillips, H.R., \& Bilgin, N. (1977). Correlation of Rock Properties with the Measured Performance of Disc Cutters. Proceedings of a Conference on Rock Engineering, University of Newcastle Upon Tyne, 181-196.

Phillips, H.R., Bilgin, N., \& Price, D.L. (1978). The Influence of Tyre Tip Geometry on the Design of Disc Cutter Arrays. Third Australian Tunnelling Conference: Preprints of Papers, 48-52.

Preis, E.V., \& Kuznetsov, V.V. (2015) Simulation of Large Volume Elements at Once or Violations Coal Disc Cutters. Mining Equipment and Electromechanics, (7), 37-41.

Rostami, J. (2013). Study of Pressure Distribution within the Crushed Zone in the Contact Area Between Rock and Disc Cutters. International Journal of Rock Mechanics and Mining Sciences, (57), 172-186. https://doi:10.1016/j.ijrmms.2012.07.031

Rostami, J., \& Ozdemir, L. (1993). A New Model for Performance Prediction of Hard Rock TBMs. Proceedings of the Rapid Excavation and Tunneling Conference, 793-809.

Rostami, J., Ozdemir, L., \& Nilson, B. (1996). Comparison between CSM and NTH Hard Rock TBM Performance Prediction Models. Proceedings of Annual Technical Meeting of the Institute of Shaft Drilling Technology, 1-10.

Roxborough, F., \& Phillips, H. (1975). Rock Excavation by Disc Cutter. International Journal of Rock Mechanics and Mining Sciences \& Geomechanics Abstracts, 12(12), 361-366. https://doi.org/10.1016/0148-9062(75)90547-1

Roxborough, F.F. (1978). Fundamental Studies on the Mechanics of Cutting Rock with Discs. Third Australian Tunnelling Conference: Preprints of Papers, 43-47.

Solod, V.I., Getopanov, V.N., \& Rachek, V.M. (1982). Proektirovanie i konstruirovanie gornyh mashin i kompleksov. Uchebnik dlja vuzov. Moskva: Nedra.

Tumac, D., \& Balci, C. (2015). Investigations into the Cutting Characteristics of CCS Type Disc Cutters and the Comparison Between Experimental, Theoretical and Empirical Force Estimations. Tunnelling and Underground Space Technology, (45), 84-98. https://doi.org/10.1016/j.tust.2014.09.009

Zhao, J., Gong, Q., \& Eisensten, Z. (2007). Tunnelling through a Frequently Changing and Mixed Ground: A Case History in Singapore. Tunnelling and Underground Space Technology, $22(4), 388-400$ https://doi.org/10.1016/j.tust.2006.10.002

Zhelykevich, R.B., Selivanov, N.I., \& Kaiser, Y.F. (2015). Determination of Stresses Caused in the Disc Cutter, Blocked Cutting of Frozen Soils. Izvestiya Tul'skogo Gosudarstvennogo Universiteta. Tekhnicheskie Nauki, 8(2), 66-78.

\section{ABSTRACT (IN UKRAINIAN)}

Мета. Дискова шарошка - основний інструмент, що застосовується для оснащення тунелепрохідницьких комплексів. Від правильності вибору інструменту залежить ефективність руйнування гірських порід, а отже, швидкість ведення гірничопрохідницьких робіт і техніко-економічні показники проекту. Таким чином, надзвичайно важливо мати надійні та точні розрахункові методи прогнозування зусиль, що виникають при руйнуванні гірських порід дисковими шарошками. Однак дослідження на пострадянському просторі у даній галузі знань обмежуються вивченням клиновидних шарошок невеликого діаметру, які в даний час практично не застосовуються. Представлена робота виконана з метою аналізу умови відповідності найвідомішого вітчизняного методу Барона-Глатмана та основних зарубіжних розрахункових методів, розроблених такими вченими як Роксборо $\mathrm{i}$ Філліпс, Більгін і Філліпс, Ростамі і Оздемір.

Методика. Аналіз міститься в короткому огляді методів, серії чисельних експериментів, які були виконані для шарошок діаметром 160 і 483 мм (малого та великого діаметру), і порівняння результатів із використанням 
графіків. Шляхом апроксимації отриманих у результаті численних експериментів даних були визначені вирази (масштабні коефіцієнти) для перерахунку значень, отриманих із використанням зарубіжних методів, до значень за методом Барона-Глатмана для тих же умов.

Результати. В існуючому вигляді метод Барона-Глатмана не може бути використаний для проектування тунелепрохідницької техніки або прогнозування ефективності ії застосування. Підхід на основі масштабних коефкоефіцієнтів може бути використаний для співвіднесення будь-яких з розглянутих методів між собою. Масштабні коефіцієнти залежать тільки від глибини різання для зусиль перекочування, глибини різання й діаметра шарошки для нормальних зусиль.

Наукова новизна. Аналіз також показав, що взаємне розташування ліній графіка для всіх фігур залишається незмінним. Інваріантність відносного позиціонування і ліній трендів графіків дозволяє зробити припущення про можливість введення масштабних коефіцієнтів, які дозволяють приводити значення від одного методу до значень інших методів. Визначення масштабного коефіцієнта, що дозволяє зв'язати вітчизняний метод 3 основними іноземними методами, здійснюється шляхом послідовного розподілу розрахункових значень, отриманих за методом Барона і Глатмана на значення для інших розглянутих методів.

Практична значимість. Отримані результати можуть бути використані при проектуванні тунелепрохідницьких комплексів та організації тунелепрохідницьких робіт.

Ключові слова: руйнування гірських порід, механічний інструмент, дискова шарошка, вітчизняні та зарубіжні методи, сила різання, масштабний коефіиієнт, перетворення методів розрахунку

\section{ABSTRACT (IN RUSSIAN)}

Цель. Дисковая шарошка - основной инструмент, применяемый для оснащения тоннелепроходческих комплексов. От правильности выбора инструмента зависит эффективность разрушения горных пород, а, следовательно, скорость ведения горнопроходческих работ и технико-экономические показатели проекта. Таким образом, чрезвычайно важно иметь надежные и точные расчетные методы прогнозирования усилий, возникающих при разрушении горных пород дисковыми шарошками. Однако исследования на постсоветском пространстве в данной области знаний ограничиваются изучением клиновидных шарошек относительно небольшого диаметра, которые в настоящее время практически не применяются. Представленная работа выполнена с целью анализа соответствия самого известного отечественного метода Барона-Глатмана и основных зарубежных расчетных методов, разработанных такими учеными как Роксборо и Филлипс, Бильгин и Филлипс, Ростами и Оздемир.

Методика. Анализ состоит в кратком обзоре методов, серии численных экспериментов, которые были выполнены для шарошек диаметром 160 и 483 мм (малого и большого диаметра), и сравнении результатов с использованием графиков. Путем аппроксимации полученных в результате численных экспериментов данных были определены выражения (масштабные коэффициенты) для пересчета значений, полученных с использованием зарубежных методов, к значениям по методу Барона-Глатмана для тех же условий.

Результаты. В существующем виде метод Барона-Глатмана не может быть использован для проектирования тоннеллепроходческой техники или прогнозирования эффективности ее применения. Подход на основе масштабных коэффициентов может быть использован для соотнесения любых из рассмотренных методов между собой. Масштабные коэффициенты зависят только от глубины резания для усилий перекатывания, глубины резания и диаметра шарошки для нормальных усилий.

Научная новизна. Анализ также показал, что взаимное расположение линий графика для всех фигур остается неизменным. Инвариантность относительного позиционирования и трендов линий графиков позволяет сделать предположение о возможности введения масштабных коэффициентов, которые позволяют приводить значения от одного метода к значениям других методов. Определение масштабного коэффициента, позволяющего связать отечественный метод с основными иностранными методами, осуществляется путем последовательного деления расчетных значений, полученных по методу Барона и Глатмана на значения для других рассмотренных методов.

Практическая значимость. Полученные результаты могут быть использованы при проектировании тоннелепроходческих комплексов и организации тоннелепроходческих работ.

Ключевые слова: разрушение горных пород, механический инструмент, дисковая шарошка, отечественные и зарубежные методы, сила резания, масштабный коэффиџиент, преобразование методов расчета

\section{ARTICLE INFO}

Received: 17 July 2017

Accepted: 11 September 2017

Available online: 30 September 2017

\section{ABOUT AUTHORS}

Aleksander Zhabin, Doctor of Technical Sciences, Professor of the Geotechnologies and Underground Construction Department, Tula State University, 90 Lenina Ave., 300600, Tula, Russia. E-mail: zhabin.tula@mail.ru

Andrei Polyakov, Doctor of Technical Sciences, Professor of the Geotechnologies and Underground Construction Department, Tula State University, 90 Lenina Ave., 300600, Tula, Russia. E-mail: polyakoff-an@mail.ru

Evgenii Averin, Candidate of Technical Sciences, Engineer-Designer of the Designing Department, LLC "SOEZ", 8 Eksperimentalnaya St, 300911, Tula, Russia. E-mail: evgeniy.averin.90@mail.ru 